\title{
Lithium Administration to Preadolescent Rats Causes Long-Lasting Increases in Anxiety-Like Behavior and Has Molecular Consequences
}

\author{
Rachael M. Youngs, ${ }^{1}$ Melissa S. Chu, ${ }^{1}$ Edward G. Meloni, ${ }^{2,3}$ Alipi Naydenov, ${ }^{1}$ William A. Carlezon Jr,${ }^{2,3}$ and \\ Christine Konradi ${ }^{1,3}$ \\ ${ }^{1}$ Laboratory of Neuroplasticity and ${ }^{2}$ Behavioral Genetics Laboratory, McLean Hospital, Belmont, Massachusetts 02478, and ${ }^{3}$ Department of Psychiatry, \\ Harvard Medical School, Boston, Massachusetts 02115
}

\begin{abstract}
Lithium (Li) is frequently used in the treatment of bipolar disorder (BPD), a debilitating condition that is increasingly diagnosed in children and adolescents. Because the symptoms of BPD in children are different from the typical symptoms in adulthood and have significant overlap with other childhood psychiatric disorders, this disorder is notoriously difficult to diagnose. This raises the possibility that some children not affected by BPD are treated with Li during key periods of brain development. The objective of this investigation was to examine the long-term effects of Li on the developing brain via a series of behavioral and molecular studies in rats. Rat pups were reared on Li chow for 3 weeks. Parallel groups were tested while on Li chow or 2 and 6 weeks after discontinuation of treatment. We found increased measures of anxiety-like behavior at all times tested. Gene microarray studies of the amygdala revealed that Li affected the expression of gene transcripts of the synapse and the cytoskeleton, suggesting that the treatment induced synaptic adjustments. Our study indicates that Li can alter the trajectory of brain development. Although the effects of Li on the normal brain seems unfavorable, effects on the abnormal brain cannot be determined from these studies alone and may well be therapeutic. Our results indicate that $\mathrm{Li}$ administration to the normal brain has the potential for lasting adverse effects.
\end{abstract}

Key words: amygdala; anxiety; behavior; development; elevated plus maze; gene expression microarrays; lithium

\section{Introduction}

Lithium (Li) is frequently used to treat bipolar disorder (BPD) in adults (American Psychiatric Association, 1994). BPD patients have often symptoms before adulthood (Carlson et al., 1977; Joyce, 1984), and 1\% of adolescents ages 14-18 years meet criteria of $\mathrm{BPD}$ or cyclothymia, considered a milder form of $\mathrm{BPD}$ (Lewinsohn et al., 1995). In recent years, diagnosis in juveniles has increased markedly, but controversy surrounds the diagnostic criteria in childhood and adolescence (Carlson, 1990; Geller and Luby, 1997; Wozniak et al., 2001; Harpaz-Rotem et al., 2005). BPD symptoms in childhood and adolescence deviate from the symptom criteria established for adults (Steele and Fisman, 1997; Wozniak et al., 2001), and diagnosis at an early age is complicated by the overlap with other childhood psychiatric disorders such as attention-deficit-hyperactivity disorder (ADHD) and conduct disorder (Geller and Luby, 1997; Hechtman and Greenfield, 1997; Geller et al., 1998; Davanzo and McCracken, 2000). Despite these problems, treatment is often initiated at an early age and, in some cases, even preschool age (Geller et al., 1995; Wozniak et al., 2001; Biederman et al., 2005).

Received Nov. 7, 2005; revised April 25, 2006; accepted April 26, 2006.

This work was supported by Grant MH63266 (W.A.C.) and by Jim and Pat Poitras (C.K.). We thank Jean Frazier, Elena Chartoff, Mark Todtenkopf, Stephan Heckers, and John Levine for advice and helpful discussions.

Correspondence should be addressed to Christine Konradi, Laboratory of Neuroplasticity, McLean Hospital, 115 Mill Street, Belmont, MA 02478. E-mail: konradi@mclean.harvard.edu.

DOI:10.1523/JNEUROSCI.0580-06.2006

Copyright $\odot 2006$ Society for Neuroscience $\quad$ 0270-6474/06/266031-08\$15.00/0
Because Li has therapeutic effects in adults with BPD, it seems a reasonable choice for younger patients. Li can be effective in children and adolescents for the treatment of mania (Biederman et al., 1998; Kowatch et al., 2000; Kafantaris et al., 2003), conduct disorder (Silva et al., 1993), and aggression (Sheard, 1975). However, drug trials tailored to children and adolescents are needed before adult medications can be deemed safe for younger patients. The immature CNS is vulnerable to the latent cognitive and neurological impact of drugs (Tueth et al., 1998), and druginduced modifications have the potential to alter the developmental trajectory of the brain (Carlezon and Konradi, 2004).

In the present study, we examined the effects of chronic Li exposure on preadolescent rats to address the question of whether Li has any long-lasting effects on brain development and behavior. We used normal rats as a model to examine how Li would affect brain development in children who receive the drug but are later rediagnosed as not having BPD. We focused on fearand anxiety-like behaviors, which are prevalent in pediatric BPD patients diagnosed with BPD (46.0-78\%) (Masi et al., 2001; Engstrom et al., 2003; Dickstein et al., 2005). Behavioral measures used included the open-field paradigm, elevated plus maze (EPM), fear-potentiated startle (FPS), locomotor activity, and the Morris water maze. These studies were combined with a gene expression microarray analysis in the amygdala, an area involved in fear and anxiety (Davis, 1997; LeDoux, 2003) that has been shown to be reduced in size in pediatric BPD patients (Chang et al., 2005).

Rat preadolescence/early adolescence was defined by the 3 
week period after weaning (Andersen, 2003; Spear, 2004), during which Li was added to the rat chow. Experiments were designed to determine behavioral adaptations after 3 weeks of Li treatment and 2 and 6 weeks after the termination of $\mathrm{Li}$ treatment. Molecular adaptations were examined during and 2 weeks after $\mathrm{Li}$ treatment.

\section{Materials and Methods}

\section{Li treatment and health maintenance}

Male Sprague Dawley rats (Taconic Farms,

Germantown, NY), postnatal day 16 (P16),

were shipped to our facility with a lactating female. A total of 340 rats was used for all experiments. Pups were housed in family units and allowed to acclimate for $4 \mathrm{~d}$. On P20, the pups were weaned and each litter was split between lithium and control chow, with four rats per cage. Care was taken that all experiments performed subsequently had equal numbers of rats of all litters. Pups were provided with preweighed aliquots of $0.15 \%$ $\mathrm{Li}$ carbonate chow or control chow (Co) balanced for nutrient content (Harlan Teklad, Madison, WI). The colony room was maintained on a $12 \mathrm{~h}$ light/dark cycle.

Pups were reared on Li/Co chow for 3 weeks (P20-P41). Food weight was recorded daily and once on the weekend, and additional chow was added as needed. Control rats were yoked to Li food intake on a cage-bycage basis. All rats were weighed twice a week, and a representative weight curve is shown (Fig. 1C). Although overall health in rats on Li diet is normal (Cappeliez, 1986; Laursen et al., 2004), rats do display polydypsia/polyurea, accompanied by sodium wasting (Lee et al., 1971; Singer et al., 1972). Therefore, all cages were equipped with a bottle of $450 \mathrm{~mm}$ $\mathrm{NaCl}$ solution, in addition to ample drinking water. Cages and bedding were changed daily for $\mathrm{Li}$ and Co rats. One rat in a control group died of unknown causes; no deaths attributable to Li treatment occurred.

\section{Calculation of Li intake}

For each $24 \mathrm{~h}$ period, the weight of Li chow consumed by one cage of rats was divided by the number of rats (four) and multiplied by the percentage of $\mathrm{Li}$ in the chow $\left(0.15 \% \mathrm{Li}_{2} \mathrm{CO}_{3}=0.03 \% \mathrm{Li}\right.$ corrected for carbonate). This value was then divided by the average weight of the rats in that cage. The resulting value, approximate $\mathrm{Li}$ intake, was expressed as milligrams of Li consumed per kilogram rat per $24 \mathrm{~h}$ (Fig. $1 \mathrm{~A}$ ). Li serum levels (LabCorp, Burlington, NC) were determined in independent groups of rats ( $n=4$ per group) that were killed at the end of each week (Fig. $1 B$ ).

\section{Timing of behavioral testing}

Rats on Li/Co chow were subjected to behavioral testing in the middle of their third week (P36). To prevent withdrawal effects during behavioral testing, Li/Co chow was extended until P44 when all testing was complete. Rats tested for prior $\mathrm{Li} / \mathrm{Co}[2 \mathrm{w}]$ exposure were kept on $\mathrm{Li}$ or Co chow for 3 weeks and then switched to normal laboratory chow ad libitum for 2 weeks before behavioral testing began. One group of rats and respective controls (prior Li/Co $[6 \mathrm{w}]$ ) were tested in the open-field paradigm 6 weeks after discontinuation of Li/Co chow. All testing was performed in parallel in Li and weight-matched Co groups.

The data for each behavioral test were collected from two to three independent experiments performed over the course of several months. Final values of $n$ are reported individually for each test. Generally, all tests were performed in independent groups of rats. However, open field and EPM were considered non-invasive, and, in some groups of rats, one of these tests was performed before FPS, Morris water maze, or molecular analysis. Rats had at least $3 \mathrm{~d}$ of rest between both tests. Control groups were always treated exactly the same as Li groups. Open field and EPM were never performed in the same group of rats.

\section{Open field}

At P37, P51, and P83, respectively, Li/Co, prior Li/Co $[2 \mathrm{w}]$, and prior $\mathrm{Li} / \mathrm{Co}[6 \mathrm{w}]$ rats were placed for $1 \mathrm{~h}$ in automated, $43 \times 43 \times 30.5 \mathrm{~cm}$ (length $\times$ width - height) locomotor activity chambers (Med Associates,
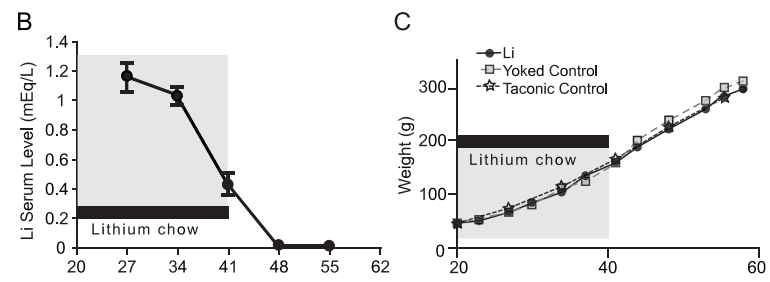

12). $\boldsymbol{B}$, At the end of each week, a group of rats was killed $(n=4)$ and serum was analyzed for Li levels. $\boldsymbol{C}$, Representative growth curve for Li rats $(n=12)$ and Co rats $(n=12)$. The growth curve was in line with the growth curve for male Sprague Dawley rats S. $\boldsymbol{B}$, , Data are average \pm SEM (in some charts, smaller than the symbol).

St. Albans, VT) to record activity levels and open-field behavior. Each unit had a white enamel floor and Plexiglas walls lined with photo beams enclosed within a sound- and light-attenuating outer chamber. A $7.5 \mathrm{~cm}$ perimeter was designated as the "exterior" zone, and the remaining square was the "interior" zone. "Box size," an internal parameter that accounts for the size of the test subject and represents the number of photobeams to be broken before a movement is considered ambulatory, was set at 2, 3, and 4 for ages P37 (Li/Co), P51 (prior Li/Co [2w]), and P83 (prior Li/Co $[6 \mathrm{w}]$ ), respectively. Data were analyzed for time spent in the interior zone/time spent in the exterior zone, distance traveled, and number of zone crossings.

\section{Elevated plus maze}

The EPM (Hamilton Kinder, Poway, CA) consisted of four black Plexiglas arms at right angles elevated $85 \mathrm{~cm}$ above ground. Two of the arms were enclosed by panels $40 \mathrm{~cm}$ high (closed arms), whereas the other two were open to the room (open arms). Each arm was $10.8 \mathrm{~cm}$ wide and 50 $\mathrm{cm}$ long.

Rats were allowed to acclimate to the procedure room in their cages for $1-2 \mathrm{~h}$ before testing. Every effort was made to prevent acoustic and visual disturbances during this time. The room was lit by a single light bulb in a corner, providing the maze with a small amount of indirect light. Sessions were filmed from overhead with a Sony (Tokyo, Japan) Handycam camcorder with "night shot" setting.

After acclimation, each rat was placed in the center facing an open arm, and behavior was recorded for exactly $5 \mathrm{~min}$. The maze was cleaned thoroughly between rats. Groups were alternated to prevent any time-ofday effects. Video of the trials was scored by a blinded observer for time spent in closed versus open arms, as well as number of open and closed arm entries. A rat was considered in an arm when its hindlegs crossed the threshold. Data were expressed as time spent in open arms over time spent in all arms.

\section{Fear-potentiated startle}

Training and testing of animals was conducted in startle cages similar to those described previously (Carlezon et al., 2005). The visual conditioned stimulus (CS) was a light produced by an $8 \mathrm{~W}$ fluorescent bulb (15 ms rise time) located $10 \mathrm{~cm}$ behind, and at a $45^{\circ}$ angle above, the startle cage. The unconditioned stimulus (US) was a shock delivered to the floor bars of each cage by a shocker/scrambler module. The calibration, presentation, and sequencing of all stimuli were under the control of the personal computer using specially designed software.

During training, rats received a $5 \mathrm{~min}$ acclimation period followed by 10 light-shock pairings consisting of a $3.7 \mathrm{~s} \mathrm{light} \mathrm{(CS)} \mathrm{coterminating} \mathrm{with}$ a $0.5 \mathrm{~s}, 0.6 \mathrm{~mA}$ footshock (US). Shock reactivity (displacement of the cage in response to the shock) was recorded after each light-shock presentation. The mean intertrial interval (for training, defined as the onset interval between successive light-shock pairings) was $3 \mathrm{~min}$ (range of 2-4 $\mathrm{min}$ ). Rats received two training sessions spaced $48 \mathrm{~h}$ apart. Twenty-four hours after the second training session, rats were placed in the startle cages, and, after a $5 \mathrm{~min}$ acclimation period, rats were presented with nine startle stimuli, three at each of three intensities $(95,100$, and $105 \mathrm{~dB})$ in a semi-random order with a $30 \mathrm{~s}$ interstimulus interval (ISI). These initial stimuli were presented to allow the startle response to become habituated and, therefore, more stable before the collection of the test 
data. Rats were then presented with nine noise-alone and nine lightnoise trials $(95,100$, and $105 \mathrm{~dB}$ noise for both trial types). For the light-noise trials, the startle-eliciting stimulus occurred $3.2 \mathrm{~s}$ after the onset of the light (i.e., the time when the shock would have occurred). All trial types were presented in a pseudorandom order (30 s ISI) with the constraint that each trial type occurred only once in each consecutive six-trial block.

\section{Morris water maze}

The Morris water maze tank was $175 \mathrm{~cm}$ in diameter and $63.5 \mathrm{~cm}$ high, filled with $35.5 \mathrm{~cm}$ of water at $22^{\circ} \mathrm{C}$ made opaque by the addition of powdered milk. A clear Plexiglas platform, $10 \mathrm{~cm}$ square, was placed $\sim 2.5 \mathrm{~cm}$ below the surface of the water least $36 \mathrm{~cm}$ away from any wall. The internal perimeter of the tank was divided into six equally spaced drop spots, each labeled above the water level by a number and a highcontrast visual cue. Training took place on 4 consecutive days (P41-P44 for rat on $\mathrm{Li} / \mathrm{Co}, \mathrm{P} 56-\mathrm{P} 59$ for prior $\mathrm{Li} / \mathrm{Co}[2 \mathrm{w}])$. On days $1-3$, each rat was subjected to six swimming trials a day with no more than $10 \mathrm{~min}$ between trials. During each trial, the rat was placed in the tank facing the wall at one of the six drop spots and allowed to swim freely for $1 \mathrm{~min}$. If the rat located the platform within the time limit, it was removed from the tank. Escape latency (1-60 s) was recorded. Rats that failed to find the platform were guided to the proper location and left there for $10 \mathrm{~s}$ before being removed. In such cases, escape latency was recorded as $90 \mathrm{~s}$. Drop spots were randomized across animals, and each animal was placed at each location once each day. On day 4, the platform was in the original position for the first four trials but was moved to a new location in a different quadrant of the tank for the next four trials (reversal). All sessions were filmed and analyzed for crossings into quadrants and total time spent in the quadrant where the platform was previously located.

\section{Statistical analyses}

The JMP program (release 5) and StatView (version 4.5) (both from SAS, Cary, NC) were used for the statistical analyses. Factorial ANOVAs and Fisher's post hoc protected $t$ tests were used to find significant changes. Values that deviated $>2$ SDs from the average were removed from the analysis, which affected between 0 and $8 \%$ of all measures within an experiment.

\section{Gene expression microarray analysis}

Treatment groups and tissue dissection. Gene array analysis was performed in the amygdala of four groups of rats ( $n=7$ per group), $\mathrm{Li} / \mathrm{Co}$ (Li chow from P20 to P41, killed at P41), and prior Li/Co [2w] (Li chow from P20 to P41, killed at P55). Rats were decapitated, and brains were removed and immediately frozen in isopentane/dry ice. Amygdala was dissected in $2 \mathrm{~mm}$ round tissue punches at $-1.7 \mathrm{~mm}$ bregma and $-2.8 \mathrm{~mm}$ bregma, yielding four punches (two slices, left and right side of brain). Each punch was $0.8 \mathrm{~mm}$ thick (Paxinos and Watson, 1998). The punches contained the central amygdaloid nucleus, basolateral amygdaloid nucleus, and basomedial amygdaloid nucleus with all their subdivisions.

RNA extraction. RNA was extracted from the tissue punches using the RNAgent kit (Promega, Madison, WI). RNA quality was assessed in an analytical gel, and $5 \mu \mathrm{g}$ of total RNA was used for cDNA synthesis with the SuperScript double-stranded cDNA synthesis kit (Invitrogen, Carlsbad, CA). In vitro transcription was performed with the Enzo-IVT kit (Enzo Biochem, Farmingdale, NY). Biotinylated RNA was hybridized to the rat RAE230A array (Affymetrix, Santa Clara, CA), and washing and staining was performed according to company protocol. Samples from individual rats were hybridized to individual arrays. The Affymetrix RAE230A array contains $\sim 15,000$ genes; each gene is represented by 11 perfectly matched 25 -mer oligonucleotides and the same number of onemismatch oligonucleotides to provide values for nonspecific binding.

Quality control criteria. Tissue preparation and RNA extractions were performed in a single batch by the same investigators to limit experimental variability. All quality control criteria defined by Affymetrix and DNA-Chip Analyzer (dChip) (Li and Wong, 2001) were met by the samples, and no differences between the experimental groups were observed. The average percentage "present" call across all arrays was $60.2 \pm$ $2.9 \%$, and the $3^{\prime} / 5^{\prime}$ glyceraldehyde-3-phosphate dehydrogenase and $\beta$-actin ratios were $1.7 \pm 1.0$ and $2.2 \pm 0.5$ (average \pm SD). Background
(58.5 \pm 5.7$)$ and noise (raw Q, $2.2 \pm 0.2)$ were comparable between all treatment groups.

Data analysis. The Gene Chip Operating Software (Affymetrix) was used to scan the chips, determine cell intensities, and examine sample quality (see above). RMAExpress (Bolstad et al., 2003; Irizarry et al., 2003) was used to calculate gene expression levels, and dChip was used for group comparisons, ANOVA, hierarchical clustering, gene classification, and linear discriminant analysis clustering. Gene Microarray Pathway Profiler (GenMAPP) (Dahlquist et al., 2002; Doniger et al., 2003) and NIH David (Dennis et al., 2003) were used to examine the biological context of the findings with help of public databases, and $>400$ local MAPPs were assembled by the investigator or obtained from www.genmapp.org. In local MAPPs, genes were organized according to their function, such as second-messenger pathways, neurotransmitter systems, kinases, phosphatases, enzymes involved in glycolysis, subunits of the proteasome, presynaptic and postsynaptic proteins, proteins of the mitochondrial respiratory chain, G-protein-coupled receptors, etc. All MAPPs were established before data analysis and were not influenced by the results.

\section{Real-time quantitative PCR}

Complementary DNA was synthesized from 500 ng of total RNA with the SuperScript First-Strand Synthesis System for real-time quantitative PCR (Q-PCR) (Invitrogen) and oligonucleotide deoxythymidine primer. A primer set for each gene was designed with the Primer3 software (www.genome.wi.mit.edu/cgi-bin/primer/primer3.cgi), for amplicons of 100-200 bp. Melt curve analysis and PAGE were used to confirm the specificity of each primer pair. A Q-PCR kit (iQ SYBR Green supermix; Bio-Rad, Hercules, CA) was used for the experiment that was performed on a DNA engine Opticon 2 (MJ Research, Waltham, MA) in a volume of $20 \mu \mathrm{l}$, with $4 \mu \mathrm{l}$ of 1:10 diluted cDNA samples and $0.3 \mu \mathrm{M}$ primers. The PCR cycling conditions were initially $50^{\circ} \mathrm{C}$ for $2 \mathrm{~min}$, followed by $95^{\circ} \mathrm{C}$ for $7 \mathrm{~min}$, followed by 39 cycles of $94^{\circ} \mathrm{C}$ for $10 \mathrm{~s}, 55^{\circ} \mathrm{C}$ for $15 \mathrm{~s}$, and $72^{\circ} \mathrm{C}$ for $30 \mathrm{~s}$. Data were collected between $72^{\circ} \mathrm{C}$ and $82^{\circ} \mathrm{C}$ depending on amplicon melt temperature. A melt curve analysis was performed at the end of each Q-PCR experiment. Dilution curves were generated for each primer pair in every experiment by diluting complementary DNA from a vehicle sample to a final concentration of $1.00,0.2$, $0.04,0.008$, and 0.0016 . The logarithm of the dilution values was plotted against the cycle values for the standard curve. Opticon Monitor Data Analysis Software version 1.4 (MJ Research) was used to analyze the data. Blanks were run with each dilution curve to control for crosscontamination. Dilution curves, blanks, and samples were run in duplicate. Reported values were normalized to general transcription factor IIB (GTFIIB UniGene ID; Rn.6109), which was not regulated in the gene arrays. $\beta$-Actin was not used because it was induced in the gene arrays.

\section{Results}

\section{Li Treatment, Li serum levels, and weight gain}

During the $21 \mathrm{~d}$ on Li chow, Li intake remained relatively stable $\sim 40 \mathrm{mg} \cdot \mathrm{kg}^{-1} \cdot \mathrm{d}^{-1}$, a dose range identical to that used in children and adolescents (Tueth et al., 1998) (Fig. 1A). Serum Li levels ranged from 0.4 to 1.2 milliequivalents per liter $(\mathrm{mEq} / \mathrm{L})$, with a sharp decline in week 3 , while rats were still on Li chow (Fig. 1B). These levels are comparable with serum Li levels in bipolar disorder patients, which range from 0.4 to $1.0 \mathrm{mEq} / \mathrm{L}$ (Perlis et al., 2002). Interestingly, Li serum levels in adult rats 1 week on Li chow were similar to the levels observed in adolescent rats 3 weeks on $\mathrm{Li}$ chow $(0.4 \mathrm{mEq} / \mathrm{L} ; n=8$ rats; $275 \mathrm{~g})$, suggesting that the higher levels of Li observed in the serum of younger rats are probably a reflection of a different metabolism in preadolescent rats rather than the decrease in Li serum levels reflecting a metabolic adaptation. Three weeks after the start of Li treatment, at P41, the rats seemed to have reached adult Li metabolism.

$\mathrm{Li}$ was undetectable 1 and 2 weeks after discontinuation of $\mathrm{Li}$ chow and in Co rats. Thus, prior Li rats ([2w] and $[6 w])$ had no detectable Li serum levels at the time of testing or in gene expression microarray analysis. Rats appeared to be well groomed and 
showed no unusual lethargy or aggression. Unlike adult rats on $\mathrm{Li}$ chow, which, in a control experiment, had a 50\% lower weight gain than their matched controls (control rats, from 250 to $369 \mathrm{~g}$; Li chow rats, from 250 to 312 g over 3 weeks; $n=8$ per group), adolescent Li rats had normal weight gain while on Li chow and after being taken off (Fig. 1C). Thus, although controls were yoked, they were not subjected to food deprivation.

\section{Li-treated rats show increased anxiety-} like behavior in the open-field test Rats on $\mathrm{Li}$ and prior $\mathrm{Li}$ rats $([2 \mathrm{w}]$ and [6w]) spent significantly less time than their respective controls in the interior part of the locomotor chamber (Fig. 2A). A significant effect of treatment $\left(F_{(5,159)}=\right.$ $30.3 ; p<0.0001)$ and age $\left(F_{(5,159)}=126.6\right.$; $p<0.0001)$ was observed, whereby $\mathrm{Li}$ treatment decreased, and age increased, time spent in the interior part of the chamber. The effect increased with age (age $\times$ treatment $\left.F_{(5,159)}=12.6 ; p<0.0001\right)$, demonstrating that rats that were not on $\mathrm{Li}$ chow had retained, and even increased, their avoidance of the open field. Post hoc Fisher's PLSD tests showed a significant difference between Li and control rats at all time points tested. Minor motor effects were observed in the open field, which affected rats that were on Li chow but not rats that were previously on Li chow. Total distance traveled was affected by age but not by treatment (Fig. $2 C$ ) (treatment, $F_{(5,159)}$ $=1.6, p=0.17$; age, $\left.F_{(5,159)}=32.9, p<0.0001\right)$, whereas zone crossings were reduced in rats on Li chow (Fig. 2D) (treatment, $F_{(5,159)}=12.4, p<0.0005$; age, $F_{(5,159)}=155.4, p<0.0001$; post hoc Fisher's PLSD, $p \leq 0.001$ in Li/Co; not significant in either prior $\mathrm{Li} / \mathrm{Co}[2 \mathrm{w}]$ or prior $\mathrm{Li} / \mathrm{Co}[6 \mathrm{w}])$.

\section{Li-treated rats show increased anxiety-like behavior in the elevated plus maze test}

In the EPM, $\mathrm{Li}$ and prior $\mathrm{Li}[2 \mathrm{w}]$ rats spent less time on the open arm than their matched controls. Treatment had a significant effect, whereas age had no effect (Fig. $2 B$ ) (treatment, $F_{(3,83)}=$ $8.5, p<0.005$; age, $\left.F_{(3,83)}=0.9, p<0.4\right)$. Post hoc Fisher's PLSD tests showed a significant difference between $\mathrm{Li}$ and control rats 2 weeks after Li chow was discontinued but showed only a trend for rats on Li chow $(p \leq 0.07)$. No differences were observed in arm crossings on the EPM (Fig. $2 E$ ).

\section{Li-treated rats show normal conditioned fear response in the fear-potentiated startle paradigm}

FPS was used to examine whether rats treated with $\mathrm{Li}$ had an altered response to conditioned fear (Fig. $3 A, B$ ). Neither juvenile rats on Li nor adult rats exposed to Li during preadolescence had an altered response in the FPS paradigm (Fig. $3 A)\left(F_{(3,41)}=1.5\right.$; $P \leq 0.22)$. A trend toward reduced shock reactivity was observed in rats exposed to $\mathrm{Li}$, but this trend did not reach significance (Fig. 3B) and did not seem to affect FPS performance (Fig. 3B, inset) $(r=0.215 ; p=0.142)$. Indeed, FPS was similar (Fig. $3 C)$ in a subset of animals that were matched to have equivalent levels of shock reactivity (Fig. 3D). Because FPS is influenced by learning and memory processes, we examined potential learning deficits
B
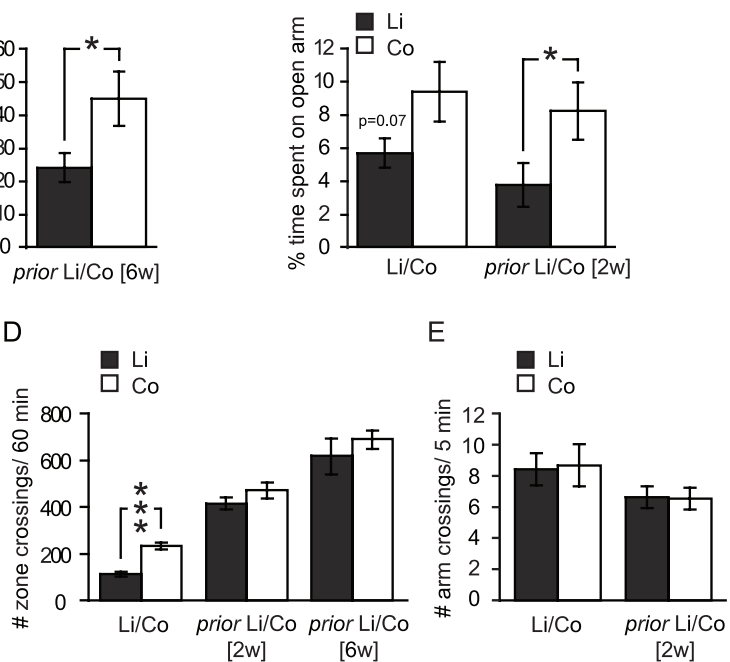

D

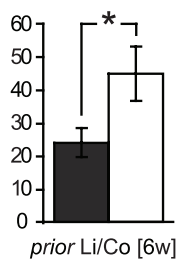

$[2 w]$
$[2 \mathrm{w}]$
$2 w]$

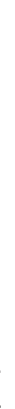

Figure 2. Open-field behavior and EPM after chronic exposure to Li. $\boldsymbol{A}$, Rats on Li chow spent significantly less time in the inner (prior Li/Co [6w]). $n=51$ for Li, 45 for Co, 24 for prior Li [2w], 24 for prior Co [2w], 10 for prior Li [6w], and 10 for prior Co [6w]. B, Rats exposed to Li during preadolescence spent less time on the open arm of the EPM than their matched controls. $n=23 \mathrm{for} \mathrm{Li}$, 24 for Co, 19 for prior Li [2w], and 21 for prior $\left.\mathrm{Co}_{[2} \mathrm{w}\right]$. C, No significant differences in total distance traveled in the locomotor chambers was observed between treatment groups; for $n$ values, see $\boldsymbol{A}$. $\boldsymbol{D}$, Zone crossings in the locomotor chambers were significantly reduced in Li-treated rats on Li but not in prior Li [2w] or in prior Li [6w] rats; for $n$ values, see $\boldsymbol{A}$. $\boldsymbol{E}$, No differences in EPM; for $n$ values, see $\boldsymbol{B}$. All data are average \pm SEM. ${ }^{*} p \leq 0.05 ;{ }^{* * *} p \leq 0.001$.

that could interfere with FPS in an independent group of rats in the Morris water maze. No difference was observed between $\mathrm{Li}$ and prior $\mathrm{Li}[2 \mathrm{w}]$ rats and their respective control groups in learning and remembering the location of the platform (Fig. 3E, days $1-4)$. There was also no difference in relearning a new position of the platform (Fig. 3E, All Reversals). Thus, juvenile Li exposure seems to affect innate anxiety but not learned fear.

\section{Gene expression microarray analysis}

Gene expression microarray analysis was performed in the amygdala. All genes that reached a $p$ value of $\leq 0.05$ and were above detection threshold ("present") in at least $50 \%$ of all samples were subjected to MAPPfinder analysis. In rats on $\mathrm{Li}, 6.9 \%$ of all genes present in at least $50 \%$ of all samples were differently regulated, with almost equal percentages upregulated and downregulated. In prior $\mathrm{Li}[2 \mathrm{w}]$ rats, $5.7 \%$ of all genes present in at least $50 \%$ of all samples were differently regulated, most of them upregulated (Fig. 4A). Transcripts with altered expression levels during Li treatment were generally different from transcripts expressed in prior $\mathrm{Li}[2 \mathrm{w}]$ rats (Fig. $4 B-D$, see numbers of overlapping genes between "on Li" and "prior Li" rats in Venn diagrams; Table 1). However, genes differently regulated in rats on Li had similar trends in prior $\mathrm{Li}[2 \mathrm{w}]$ rats. This is demonstrated by the many genes that reached significance when both groups were combined (Fig. 4B-D, "all Li versus all controls"). Only five genes were regulated in opposite directions (Fig. $4 E, F$ ). Many of the transcripts affected by Li treatment indicated structural adjustments. They included synaptic vesicle genes, cytoskeletal genes, and genes involved in cell adhesion (Table 1). Genes involved in the inositol phosphate pathway were also affected by Li treatment, in line with the notion that Li may exert its therapeutic action by interfering with the metabolism of phosphoinositides (Baraban et al., 1989), although this theory is controversial (Berry et al., 2004). Many genes affected by Li treatment clustered into functional groups such as GTP metabolism, potassium channels, and 

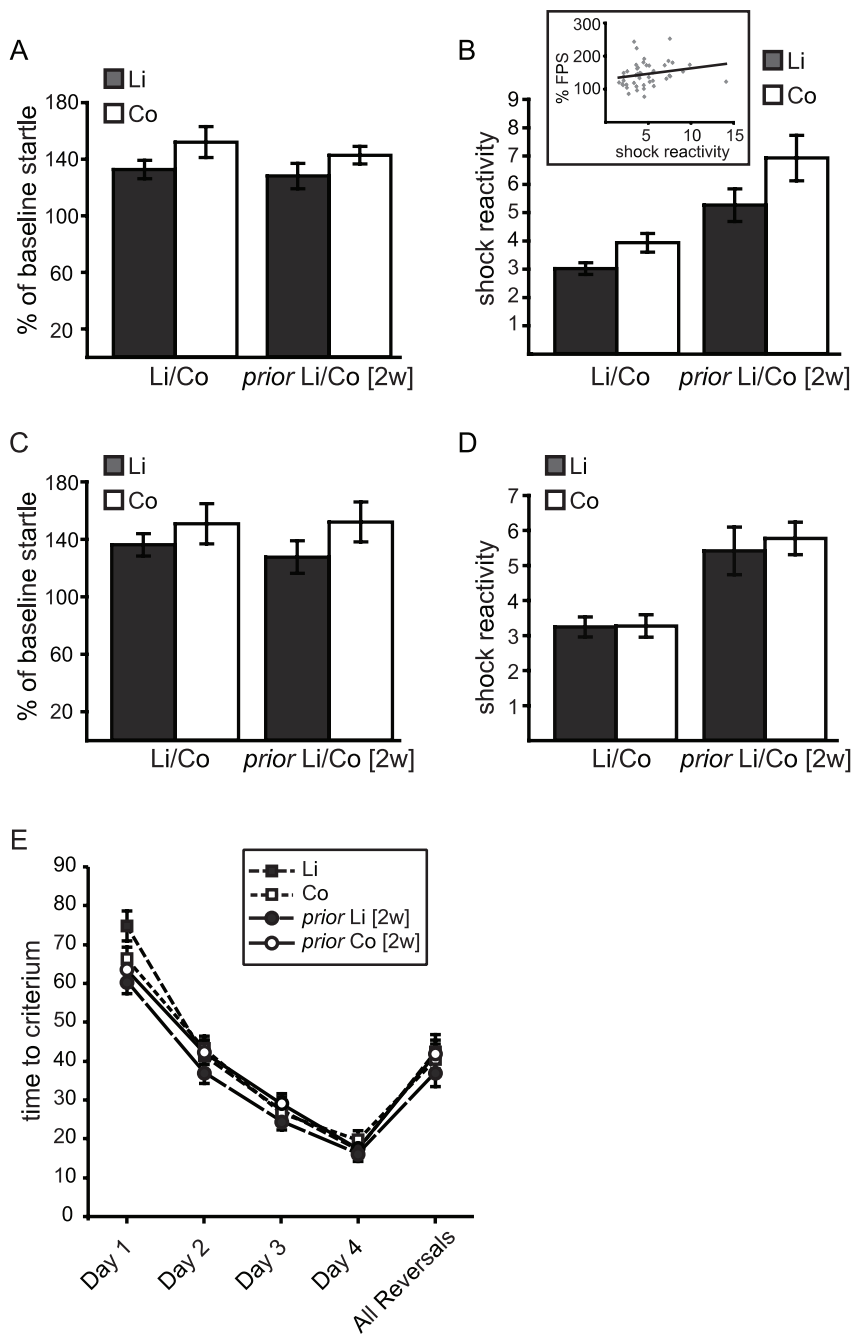

Figure 3. Fear-potentiated startle and Morris water maze. $\boldsymbol{A}$, FPS as percentage of baseline startle (ratio of response on light + startle trials - startle alone trials/startle alone) in juvenile rats on Li chow (left) and rats 2 weeks after discontinuation of Li chow (right). No difference in FPS was observed in either group; $n=11$ per group. $\boldsymbol{B}$, Rats on Li or prior Li [2w] had a trend toward lower shock reactivity, but differences were not significant; $n=12$ per group. A nonsignificant correlation was observed between shock reactivity and percentage of FPS (inset; $r=$ $0.215 ; p=0.142)$. C, Subgroups of rats with comparable shock reactivity $(\boldsymbol{D})$ did not show differences in percentage of FPS either; $n=9$ per group for $\boldsymbol{C}$ and $\boldsymbol{D}$. $\boldsymbol{E}$, No differences were observed in the ability to learn, remember, or relearn the position of the platform of the Morris water maze ( $n=10$ in Li and control; $n=18$ in prior Li [2w] and prior Co [2w]).

ATPase activity. Four transcripts were subjected to Q-PCR analysis (Fig. 5), which reflected the general pattern of regulation observed in gene arrays. The transcripts were chosen based on fold difference and level of significance in the gene expression microarray analysis, combined with their representation of individual groups of altered transcripts.

\section{Discussion}

Rats treated with Li during preadolescence showed increased measures of innate anxiety in the open field and on the EPM. The open-field test relies on a rodent's innate exploratory behavior counteracted by its natural aversion to open space. The time spent in the interior of the box is related to the exploratory behavior of a rat and inversely related to the anxiety level (Crawley, 1985). Avoidance of the open field was observed during Li administration and 2 weeks after Li administration was concluded. A group of rats was tested in the locomotor chambers 6 weeks
A

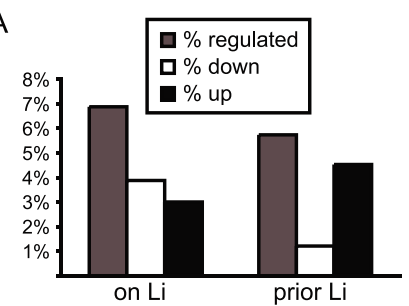

C

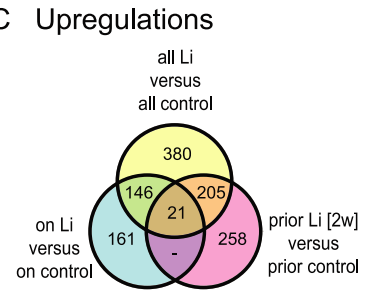

B Any regulation

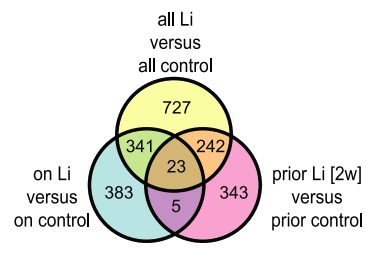

D Downregulations

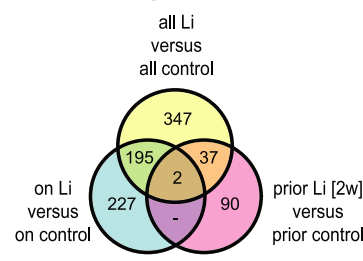

E Up- versus downregulation

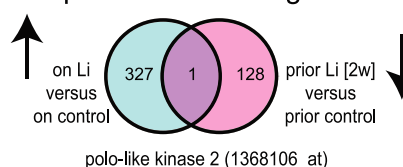

polo-like kinase 2 (1368106_at)

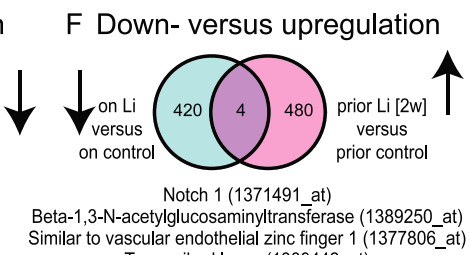

Transcribed locus (1389442
Figure 4. Gene expression patterns in the amygdala. Percentage of all genes with altered regulation in rats on Li and prior Li [2W] rats. Only genes that were expressed in at least $50 \%$ of all samples ( $n=10,933$ in rats on Li and 10,685 in prior Li [2w]) were included in the calculation. $\boldsymbol{B}-\boldsymbol{F}$, Venn diagrams of genes with overlapping regulations. $n=6$ per group.

after discontinuation of Li chow. At this point, in adulthood, they still spent less time in the open/inner area of the locomotor box than their age- and weight-matched controls. The anxiety-like behavior was more pronounced after Li administration had ended, suggesting that preadolescent Li administration alters brain function beyond the time of exposure. Li and Co rats had similar locomotor measures in the open-field chamber 2 and 6 weeks after discontinuation of Li/Co exposure. Therefore, the altered behavior in the locomotor chamber was unlikely to be attributable to locomotor differences. Increased anxiety in Li rats was further supported by results with the EPM, which is one of the most widely used behavioral tests to examine innate anxiety. Normal rats placed in the maze for the first time tend to spent much of their time in the closed arms. Treatment with anxiolytic drugs increases the time spent in the open arms and the number of open arm entries, whereas anxiogenic drugs have the opposite effect (Pellow et al., 1985; Brett and Pratt, 1990; Treit et al., 1993; Dawson and Tricklebank, 1995). Rats exposed to Li in our study spent less time on the open arm than their matched controls, an anxiogenic-like effect that was significant in rats on prior $\mathrm{Li}[2 \mathrm{w}]$ chow. Arm crossings were the same in all groups, indicating no differences in motor activity.

Results from the FPS paradigm suggest that conditioned fear is not significantly affected by Li exposure. FPS is a measure of fear-like behaviors induced by pairing an electric shock with a conditioned stimulus (light) and using the acoustic startle response as a measurable response to the conditioned stimulus (Brown et al., 1951; Davis and Astrachan, 1978; Grillon and Davis, 1997). In the present study, we found that this conditioned response (the potentiation of startle in the presence of the light) was similar between control and Li-treated rats. Shock reactivity 
Table 1.

\begin{tabular}{|c|c|c|c|c|c|c|c|}
\hline \multirow[b]{2}{*}{ synaptic vesicles } & \multirow{2}{*}{ probe set } & \multirow[b]{2}{*}{ gene } & \multirow{2}{*}{ LocusLink ID } & \multicolumn{2}{|c|}{ on $\mathrm{Li}$} & prior L & {$[2 w]$} \\
\hline & & & & fold change & $P$ value & fold change & $P$ value \\
\hline upregulated by lithium & 1368865_at & synaptoporin & 66030 & 1.26 & 0.009 & 1.01 & 0.791 \\
\hline & 1368276_at & synaptophysin & 24804 & 1.19 & 0.037 & -1.22 & 0.078 \\
\hline & 1370718_at & synaptotagmin $\mathrm{X}$ & 60567 & 1.10 & 0.050 & 1.05 & 0.257 \\
\hline downregulated by lithium & 1368246 at & adaptor-related protein complex 3 , mu 2 subunit & 140667 & -2.02 & 0.043 & -1.30 & 0.258 \\
\hline & 1369058_at & synaptotagmin 3 & 25731 & -1.43 & 0.014 & -1.23 & 0.070 \\
\hline & 1388193_at & huntingtin interacting protein 1 & 192154 & -1.38 & 0.017 & -1.24 & 0.164 \\
\hline & 1372950_at & blocked early in transport 1 -like & 54400 & -1.36 & 0.027 & -1.13 & 0.299 \\
\hline & 1373510_at & vesicle-associated membrane protein 1 & 25624 & -1.24 & 0.018 & 1.09 & 0.386 \\
\hline & 1370840_at & syntaxin binding protein 1 & 25558 & -1.22 & 0.023 & -1.13 & 0.205 \\
\hline & 1398330_at & syntaxin binding protein 1 & 25558 & -1.13 & 0.018 & -1.08 & 0.103 \\
\hline upregulated in prior lithium & 1372474_at & pantophysin & 366595 & 1.13 & 0.302 & 1.46 & 0.005 \\
\hline & 1373024_at & adaptor-related protein complex 3, sigma 1 subunit & 302290 & 1.13 & 0.399 & 1.37 & 0.027 \\
\hline & 1398843_at & vesicle-associated membrane protein, associated protein a & 58857 & 1.09 & 0.399 & 1.23 & 0.030 \\
\hline & 1372628_at & adaptor-related protein complex AP-4, sigma 1 & 366618 & 1.09 & 0.573 & 1.32 & 0.034 \\
\hline downregulated in prior lithium & 1369627_at & synaptic vesicle glycoprotein $2 b$ & 117556 & 1.02 & 0.914 & -2.41 & 0.047 \\
\hline & 1369332_a_at & regulating synaptic membrane exocytosis 1 & 84556 & -1.07 & 0.649 & -1.35 & 0.044 \\
\hline & & & & & & prior L & {$[2 w]$} \\
\hline cell adhesion & probe set & gene & LocusLink ID & fold change & Pvalue & fold change & $P$ value \\
\hline upregulated by lithium & 1367888_at & MT-protocadherin & 93662 & 1.33 & 0.018 & -1.05 & 0.690 \\
\hline & 1369351_at & contactin 3 & 54279 & 1.12 & 0.019 & 1.15 & 0.017 \\
\hline downregulated by lithium & 1372447_at & fibroblast growth factor receptor 1 & 79114 & -1.50 & 0.001 & -1.14 & 0.355 \\
\hline & 1373636_at & sparc/osteonectin, cwcv and kazal-like domains proteoglycan 1 & 306759 & -1.25 & 0.005 & 1.05 & 0.450 \\
\hline & 1373470 at & beta-catenin & 84353 & -1.13 & 0.006 & -1.00 & 0.963 \\
\hline & 1367807_at & procollagen-lysine, 2-oxoglutarate 5-dioxygenase 1 & 116552 & -1.28 & 0.006 & 1.05 & 0.690 \\
\hline & 1371921_at & catenin, alpha $1,102 \mathrm{kDa}$ & 307505 & -1.16 & 0.013 & 1.04 & 0.195 \\
\hline & 1387498_a_at & fibroblast growth factor receptor 1 & 79114 & -1.85 & 0.013 & -1.24 & 0.312 \\
\hline & 1368699_at & Down syndrome cell adhesion molecule & 171119 & -1.23 & 0.017 & -1.10 & 0.405 \\
\hline & 1387320_a_at & densin-180 & 117284 & -1.17 & 0.018 & -1.14 & 0.210 \\
\hline & 1368685_at & chondroitin sulfate proteoglycan 4 & 81651 & -1.18 & 0.019 & 1.01 & 0.939 \\
\hline & 1370954_at & procollagen-proline, 2-oxoglutarate 4-dioxygenase, alpha 1 & 64475 & -1.33 & 0.021 & 1.09 & 0.335 \\
\hline & 1368577_at & gap junction membrane channel protein beta 6 & 84403 & -1.36 & 0.025 & -1.07 & 0.616 \\
\hline & 1373124_at & tyrosine protein kinase pp60-c-src & 83805 & -1.49 & 0.028 & -1.29 & 0.136 \\
\hline & 1389030_a_at & tyrosine protein kinase pp60-c-src & 83805 & -1.37 & 0.028 & -1.15 & 0.220 \\
\hline & 1388703_at & endothelial cell adhesion molecule & 300519 & -1.23 & 0.029 & -1.04 & 0.606 \\
\hline & 1367880_at & laminin, beta 2 & 25473 & -1.27 & 0.033 & -1.23 & 0.156 \\
\hline & 1398922 at & collagen alpha1 type VI & & -1.69 & 0.040 & -1.43 & 0.166 \\
\hline & 1374239_at & FERM, RhoGEF and pleckstrin domain protein 2 & 316639 & -1.14 & 0.044 & -1.03 & 0.501 \\
\hline & 1369103_at & fyn proto-oncogene & 25150 & -1.51 & 0.045 & -1.07 & 0.543 \\
\hline & 1388388_at & bonecartilage proteclycan 1 & & -1.26 & 0.047 & 1.08 & 0.615 \\
\hline & 1373101_at & phosphatidylinositol glycan, class $\mathrm{K}$ & 295543 & -1.24 & 0.049 & -1.08 & 0.552 \\
\hline upregulated in prior lithium & 1374870_at & collagen, type XXVII, alpha 1 & 298101 & 1.03 & 0.568 & 1.13 & 0.031 \\
\hline & 1388045_a_at & cadherin 22 & 29182 & 1.06 & 0.619 & 1.20 & 0.042 \\
\hline downregulated in prior lithium & 1369793_a_at & melanoma cell adhesion molecule & 78967 & -1.28 & 0.136 & -1.31 & 0.034 \\
\hline & 1368895_at & neuroligin 2 & 117096 & 1.07 & 0.342 & -1.19 & 0.014 \\
\hline & 1388038_at & attractin & 83526 & -1.02 & 0.806 & -1.18 & 0.031 \\
\hline & & & & & & prior L & {$[2 w]$} \\
\hline cytoskeleton & probe set & gene & LocusLink ID & fold change & P value & fold change & $P$ value \\
\hline upregulated by lithium & 1372195_at & troponin $\mathrm{C}_{2}$, fast & 296369 & 1.32 & 0.005 & -1.10 & 0.117 \\
\hline & 1370697_a_at & nexilin & 246172 & 1.20 & 0.046 & 1.11 & 0.127 \\
\hline & 1370513_at & tropomyosin 1, alpha & 24851 & 1.14 & 0.001 & 1.06 & 0.412 \\
\hline & 1370158_at & myosin heavy chain 10 & 79433 & 1.15 & 0.008 & 1.01 & 0.690 \\
\hline & 1371511_at & actin related protein $2 / 3$ complex, subunit 2 & 301511 & 1.14 & 0.044 & 1.11 & 0.174 \\
\hline & 1388128_at & actin-related protein 3 & 81732 & 1.05 & 0.041 & -1.02 & 0.724 \\
\hline & 1367457_at & beclin 1 & 114558 & 1.07 & 0.025 & 1.05 & 0.242 \\
\hline downregulated by lithium & 1373478_at & myosin binding protein $\mathrm{H}$ & & -1.67 & 0.036 & -1.37 & 0.115 \\
\hline & 1371866_at & myosin XVIIIa & 287905 & -1.52 & 0.041 & -1.16 & 0.521 \\
\hline & 1373706_at & actin dependent regulator of chromatin, a-like 1 & 316477 & -1.46 & 0.009 & -1.05 & 0.654 \\
\hline & 1368250_at & tektin 1 & 85270 & -1.43 & 0.019 & -1.22 & 0.392 \\
\hline & 1377692 at & smooth muscle myosin heavy chain 11 isoform SM1-like & 362697 & -1.26 & 0.032 & -1.02 & 0.757 \\
\hline & 1387866_at & myosin IXb & 25486 & -1.22 & 0.021 & -1.02 & 0.827 \\
\hline upregulated in prior lithium & 1371087_a_at & microtubule-associated protein 6 & 29457 & 1.17 & 0.323 & 1.32 & 0.046 \\
\hline & 1376785_at & synaptonemal complex protein 3 & & 1.18 & 0.274 & 1.31 & 0.036 \\
\hline & 1371716_at & actin dependent regulator of chromatin, $\mathrm{c} 2$ & 362815 & -1.17 & 0.181 & 1.30 & 0.035 \\
\hline & 1373849_at & actin-related protein BAF53a & 361925 & 1.09 & 0.204 & 1.22 & 0.010 \\
\hline & 1375863_a_at & gamma-tubulin complex component 4 & 368168 & 1.05 & 0.505 & 1.21 & 0.008 \\
\hline & 1376005_at & kinesin family $1 B$ & 117548 & 1.05 & 0.543 & 1.21 & 0.013 \\
\hline & 1372444_at & kinesin heavy & 117550 & 1.22 & 0.055 & 1.21 & 0.035 \\
\hline & 1374573 at & dynein 2 light intermediate chain & 298767 & 1.07 & 0.271 & 1.13 & 0.017 \\
\hline downregulated in prior lithium & 1393418_at & tropomodulin 2 & 58814 & -1.05 & 0.933 & -1.46 & 0.024 \\
\hline & 1369541_at & tropomodulin 2 & 58814 & -1.10 & 0.490 & -1.32 & 0.010 \\
\hline & 1373268_at & microtubule-associated protein 4 & 367171 & 1.04 & 0.718 & -1.33 & 0.043 \\
\hline & 1368137_at & microtubule-associated protein tau & 29477 & -1.10 & 0.369 & -1.10 & 0.049 \\
\hline & 1369720_at & myosin Ib & 117057 & 1.23 & 0.364 & -1.31 & 0.010 \\
\hline & 1370933_at & myosin IE & 25484 & -1.06 & 0.532 & -1.14 & 0.045 \\
\hline & 1368450_at & myosin $\mathrm{Va}$ & 25017 & 1.14 & 0.169 & -1.14 & 0.020 \\
\hline & 1371053_at & myosin, heavy 8 & 252942 & 1.01 & 0.825 & -1.07 & 0.024 \\
\hline & 1374403_at & ephrin B1 & 25186 & -1.12 & 0.119 & -1.11 & 0.013 \\
\hline & 1387552_at & discs, large homolog-associated protein 2 & 116681 & -1.05 & 0.328 & -1.23 & 0.009 \\
\hline
\end{tabular}


Table 1. Continued

\begin{tabular}{|c|c|c|}
\hline \multirow{6}{*}{$\begin{array}{l}\text { inositol phosphate pathway } \\
\text { upregulated by lithium }\end{array}$} & probe set & gene \\
\hline & 1370585_a_at & protein kinase $C$, beta 1 \\
\hline & 1370025_at & phosphatidylinositol-4-phosphate 5-kinase, type II, gamma \\
\hline & 1371014 at & phospholipase C, beta 1 \\
\hline & 1399125 at & inositol polyphosphate-1-phosphatase \\
\hline & 1388502 at & inositol-1,4,5-trisphosphate 5-phosphatase, type II \\
\hline \multirow[t]{7}{*}{ downregulated by lithium } & 1370114_a_at & phosphatidylinositol 3-kinase, regulatory subunit, polypeptide 1 \\
\hline & 1387904_at & inositol hexaphosphate kinase 1 \\
\hline & 1372074_at & diphosphoinositol polyphosphate phosphohydrolase; DIPP \\
\hline & 1388933_at & inositol 1,3,4-triphosphate 5/6 kinase \\
\hline & 1373101_at & phosphatidylinositol glycan, class K \\
\hline & 1375272_at & phosphatidylinositol 4-kinase type II \\
\hline & 1389723_at & phosphoinositide-3-kinase, regulatory subunit 4, p150 \\
\hline \multirow[t]{9}{*}{ upregulated in prior lithium } & 1371776_at & phosphatidylinositol 3-kinase, regulatory subunit, polypeptide 1 \\
\hline & 1370948_a_at & myristoylated alanine-rich C-kinase substrate (MARCKS) \\
\hline & 1373432_at & myristoylated alanine-rich C-kinase substrate (MARCKS) \\
\hline & 1369944_at & MARCKS-like protein \\
\hline & 1389143_at & phosphatidylinositol 3-kinase, catalytic, alpha polypeptide \\
\hline & 1377735_at & phosphoinositol 4-phosphate adaptor Protein-1 \\
\hline & 1389176 at & inositol polyphosphate-5-phosphatase F \\
\hline & 1375600 at & Similar to phosphatidylinositol-glycan biosynthesis, class 0 \\
\hline & 1386883_at & glycogen synthase kinase 3 alpha \\
\hline \multirow[t]{2}{*}{ downregulated in prior lithium } & 1369039_at & phosphatidylinositol 4-kinase, catalytic, beta polypeptide \\
\hline & 1387847_at & phosphatidylinositol 3-kinase, catalytic, beta polypeptide \\
\hline \multirow{12}{*}{$\begin{array}{l}\text { GTP/GDP synthesis } \\
\text { upregulated by lithium }\end{array}$} & probe set & gene \\
\hline & 1368154_at & guanylate cyclase 1 , soluble, alpha 3 \\
\hline & 1369097_s_at & guanylate cyclase 1 , soluble, beta 3 \\
\hline & 1374389_at & guanylate cyclase 1 , soluble, beta 3 \\
\hline & 1374872_at & RAS guanyl releasing protein 2 \\
\hline & 1383322_at & RAS-like family 11 member B \\
\hline & 1368505_at & regulator of G-protein signaling 4 \\
\hline & 1368500_a_at & regulator of G-protein signaling 9 \\
\hline & 1372065_at & ADP-ribosyltransferase 3 \\
\hline & 1382105_at & guanine nucleotide binding protein, beta 5 \\
\hline & 1370122_at & RAB27B \\
\hline & 1376573 at & RAB34 \\
\hline \multirow[t]{3}{*}{ downregulated by lithium } & 1373572_at & GTP binding protein 5 \\
\hline & 1370202 at & HRAS like suppressor \\
\hline & 1371836_at & RAB5C \\
\hline \multirow[t]{5}{*}{ upregulated in prior lithium } & 1388800 at & RAB5A \\
\hline & 1368847_at & RAB10 \\
\hline & 1372404_at & RAS-related C3 botulinum substrate 2 \\
\hline & 1369614_at & RAP2B \\
\hline & 1373658 at & GTPase-activating protein \\
\hline \multirow[t]{3}{*}{ downregulated in prior lithium } & 1371723_at & Ras-related GTP binding $C$ \\
\hline & 1373894_at & RAB31 \\
\hline & 1371659_at & ras homolog gene family, member $\mathrm{C}$ \\
\hline \multirow{7}{*}{$\begin{array}{l}\text { potassium channel } \\
\text { upregulated by lithium }\end{array}$} & probe set & gene \\
\hline & 1369487 a at & potassium inwardly-rectifying channel, subfamily ], member 4 \\
\hline & 1371114 at & potassium inwardly-rectifying channel, subfamily ], member 4 \\
\hline & 1387881_at & potassium channel, subfamily $\mathrm{V}$, member 1 \\
\hline & 1370439_a_at & potassium voltage gated channel, Shaw-related subfamily, member 2 \\
\hline & 1368524_at & potassium voltage gated channel, Shaw-related, member 1 \\
\hline & 1388225 at & potassium voltage gated channel, Shaw-related, member 2 \\
\hline \multirow{3}{*}{$\begin{array}{l}\text { ATPases } \\
\quad \text { upregulated by lithium }\end{array}$} & probe set & gene \\
\hline & 1368698_at & ATPase, Ca++ transporting, plasma membrane 2 \\
\hline & 1386937_at & ATPase, $\mathrm{Na}+/ \mathrm{K}+$ transporting, beta 1 \\
\hline \multirow[t]{3}{*}{ downregulated by lithium } & 1398862_at & ATPase, Ca++ transporting, cardiac muscle, slow twitch 2 \\
\hline & 1371925 at & ATPase type $13 \mathrm{~A}$ \\
\hline & 1374431_at & ATPase, $\mathrm{H}+$ transporting, $\mathrm{V} 1$ subunit $\mathrm{A}$, isoform 1 \\
\hline downregulated in prior lithium & 1371402 at & ATPase, $\mathrm{H}+$ transporting, lysosomal, beta $56 / 58 \mathrm{kDa}$, isoform 2 \\
\hline
\end{tabular}

LocusLink ID
25023
140607
24654
316376
362590
25513
50560
294292
314398
295543
114554
363131
25513
294446
294446
81520
170911
295674
309008
313341
81747
85243

\begin{tabular}{|c|c|}
\hline \multicolumn{2}{|c|}{ on Li } \\
\hline fold change & $P$ value \\
\hline 1.23 & 0.004 \\
\hline 1.23 & 0.032 \\
\hline 1.23 & 0.042 \\
\hline 1.18 & 0.010 \\
\hline 1.11 & 0.014 \\
\hline-2.19 & 0.040 \\
\hline-1.62 & 0.013 \\
\hline-1.34 & 0.043 \\
\hline-1.28 & 0.017 \\
\hline-1.24 & 0.049 \\
\hline-1.20 & 0.036 \\
\hline-1.17 & 0.025 \\
\hline 1.39 & 0.188 \\
\hline 1.11 & 0.566 \\
\hline 1.10 & 0.619 \\
\hline-1.02 & 0.858 \\
\hline 1.13 & 0.550 \\
\hline 1.16 & 0.282 \\
\hline 1.10 & 0.269 \\
\hline 1.09 & 0.233 \\
\hline 1.04 & 0.579 \\
\hline-1.12 & 0.557 \\
\hline-1.06 & 0.538 \\
\hline
\end{tabular}

LocusLink ID

2520

25202

25202

361714

305302

29480

2948

305235

363410

360571

287709

64633

50993

366957

170923

315298

246324

295342

\begin{tabular}{rr}
\multicolumn{2}{|c}{ on Li } \\
fold change & P value \\
1.39 & 0.029 \\
1.28 & 0.001 \\
1.26 & 0.019 \\
1.52 & 0.039 \\
1.42 & 0.006 \\
1.38 & 0.005 \\
1.48 & 0.036 \\
1.30 & 0.009 \\
1.28 & 0.027 \\
1.11 & 0.021 \\
1.17 & 0.023 \\
-1.27 & 0.037 \\
-1.41 & 0.009 \\
-1.49 & 0.020 \\
1.13 & 0.320 \\
1.19 & 0.292 \\
1.00 & 0.908 \\
-1.01 & 0.863 \\
-1.03 & 0.537 \\
1.05 & 0.546 \\
1.03 & 0.807 \\
1.02 & 0.901
\end{tabular}

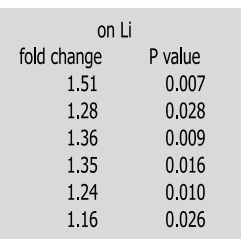

$\begin{array}{rr}\text { fold change }^{\text {on } L} & \\ 1.34 & \text { P value } \\ 1.10 & 0.041 \\ -1.52 & 0.050 \\ -1.33 & 0.020 \\ -1.09 & 0.029 \\ -1.13 & 0.036 \\ & 0.180\end{array}$

LocusLink ID
116649
116649
6032
246153
2532
246153

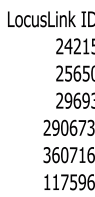

\begin{tabular}{rr}
\multicolumn{3}{c}{ prior Li/Co [2W] } \\
fold change & P value \\
-1.02 & 0.819 \\
-1.08 & 0.172 \\
1.14 & 0.159 \\
1.01 & 0.945 \\
1.06 & 0.374 \\
-1.33 & 0.055 \\
-1.24 & 0.260 \\
-1.15 & 0.201 \\
-1.08 & 0.354 \\
-1.08 & 0.552 \\
-1.05 & 0.543 \\
-1.05 & 0.453 \\
1.58 & 0.018 \\
1.46 & 0.037 \\
1.35 & 0.027 \\
1.18 & 0.016 \\
1.44 & 0.022 \\
1.34 & 0.019 \\
1.28 & 0.013 \\
1.15 & 0.034 \\
1.12 & 0.028 \\
-1.61 & 0.033 \\
-1.31 & 0.033
\end{tabular}

\begin{tabular}{|c|c|}
\hline \multicolumn{2}{|c|}{ prior Li/Co [2w] } \\
\hline fold change & $P$ value \\
\hline 1.24 & 0.137 \\
\hline 1.19 & 0.254 \\
\hline 1.22 & 0.066 \\
\hline 1.01 & 0.985 \\
\hline 1.05 & 0.607 \\
\hline-1.11 & 0.307 \\
\hline-1.02 & 0.765 \\
\hline 1.04 & 0.456 \\
\hline-1.01 & 0.917 \\
\hline 1.11 & 0.074 \\
\hline 1.06 & 0.421 \\
\hline 1.06 & 0.553 \\
\hline-1.03 & 0.891 \\
\hline-1.28 & 0.119 \\
\hline 1.32 & 0.044 \\
\hline 1.42 & 0.046 \\
\hline 1.14 & 0.022 \\
\hline 1.30 & 0.028 \\
\hline 1.10 & 0.009 \\
\hline-1.18 & 0.039 \\
\hline-1.27 & 0.048 \\
\hline-1.18 & 0.033 \\
\hline
\end{tabular}

\begin{tabular}{cr}
\multicolumn{3}{c}{ prior Li/Co [2W] } \\
fold change & P value \\
-1.09 & 0.823 \\
1.03 & 0.719 \\
1.02 & 0.741 \\
1.18 & 0.252 \\
-1.06 & 0.521 \\
-1.01 & 0.906
\end{tabular}

\begin{tabular}{cr}
\multicolumn{3}{c}{ prior Li/Co [2W] } \\
fold change & P value \\
-1.37 & 0.065 \\
1.01 & 0.831 \\
-1.15 & 0.438 \\
-1.13 & 0.274 \\
-1.03 & 0.575 \\
-1.27 & 0.011
\end{tabular}

levels (a measure of sensorimotor processes) were also similar between control and Li-treated rats, suggesting that exposure to lithium does not interfere with the ability to detect or respond to painful stimuli. Because FPS is also a measure of learning and memory processes, we tested Li-treated rats in the Morris water maze to examine whether a potential impairment of memory processes might have obstructed fear potentiation (D'Hooge and De Deyn, 2001). However, no differences were evident in the acquisition or retention phase, or in relearning the new location of the platform. Together, these results suggest that behavioral measures of innate anxiety (open field and EPM), but not conditioned fear (FPS) or spatial memory (Morris water maze), reveal the enduring consequences of Li exposure early in life.

Because of the lasting behavioral effects of adolescent Li administration, we examined whether Li alters gene expression and may thereby convey synaptic reorganization and "neuronal memory" of Li exposure (Bailey et al., 1996; Silva, 2003; Klann and Dever, 2004). Because the strength of gene array experiments is their emphasis on broad, biological themes rather than on specific genes (Konradi, 2005), we analyzed gene expression pat- 
A
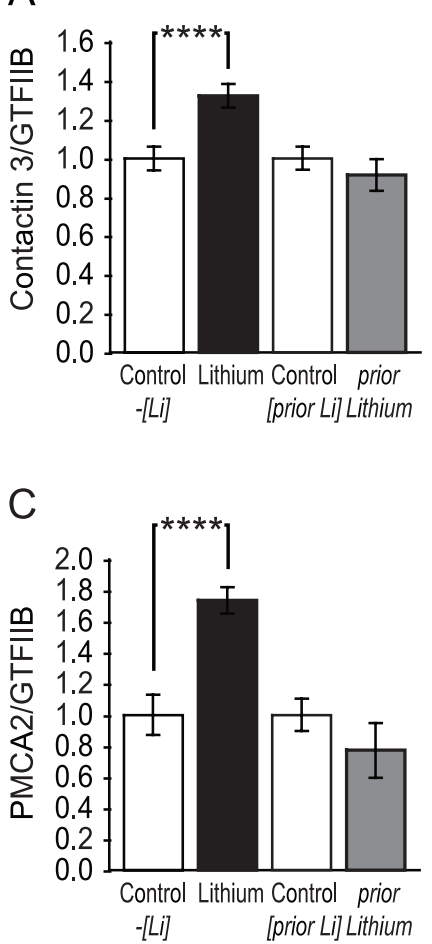
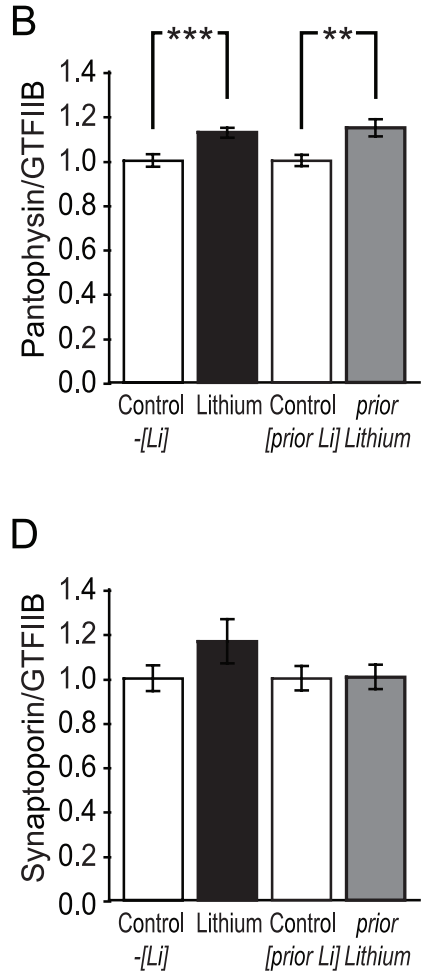

Figure 5. Q-PCR verification of gene array data. The expression of four genes was tested with Q-PCR. A, Contactin 3; $\boldsymbol{B}$, pantophysin; $\boldsymbol{C}$, plasma membrane $\mathrm{Ca}^{2+}$-transporting ATPase (PMCA2); and $\boldsymbol{D}$, synaptoporin. All genes were normalized to general transcription factor IIB (GTFIIB), which was not regulated in the gene arrays. Data are mean \pm SEM of $n=6-8$ samples. ${ }^{* *} p \leq 0.01 ;{ }^{* * *} p \leq 0.005 ;{ }^{* * * *} p \leq 0.001$.

terns during and 2 weeks after Li administration in a gene expression microarray approach. We chose the amygdala as the brain area of interest, because it is known to be involved in mechanisms of fear and anxiety (Davis, 1997; LeDoux, 2003). Gene expression in the amygdala was altered by Li treatment and affected transcripts that are involved in cell adhesion and in the structure of synapses and cytoskeleton. These changes, if translated into protein levels, indicate structural rearrangements of neurons. Although most of the altered gene expression was transient and not observed 2 weeks after discontinuation of $\mathrm{Li}$ administration, it cannot be concluded that the rearrangements themselves were reversible. Even if gene expression patterns went back to control levels, synaptic connections might have changed during the time of altered gene expression. Neuronal or dendritic rearrangements could have far-reaching consequences particularly in an immature brain, and they could explain the long-lasting effects on anxiety observed in our study. Two weeks after discontinuation of Li exposure, gene expression changes were observed in the same gene families affected during Li treatment but in a different set of transcripts and to a lesser degree. However, these modifications did not normalize the anxiety-like behavior.

Other gene families affected by Li treatment included the inositol phosphate pathway and GTPases, two pathways that can interact with each other (Alonso et al., 1988; Huang et al., 1988). Depletion of brain inositol levels has been hypothesized to be important for the therapeutic action of Li (Berridge et al., 1982; Williams et al., 2002; Harwood, 2005), although this theory is controversial (Berry et al., 2004). Interestingly, peptidylglycine $\alpha$-amidating monooxygenase, an enzyme that was shown previously to be upregulated by inositol depletion in adult rat cortical slices (Brandish et al., 2005), was downregulated in the amygdala

in our study after chronic Li treatment. This finding could be explained as differences between chronic and acute treatment paradigms, by the different experimental approaches applied, or as differences in gene expression patterns in different brain areas, as has been shown previously (MacDonald et al., 2004).

Two more gene families affected by Li were potassium channel transcripts and ATPases. These data suggest altered ion flux/ion homeostasis after Li exposure. Potassium channels are chiefly responsible for repolarizing cell membranes after action potentials. Six potassium channel subunits were upregulated during Li exposure, indicating an increased demand for repolarization, possibly caused by increased depolarization or by hypopolarization of nerve cells. ATPases are enzymes involved in ion transport, vesicle transport, and lysosomal acidification. We found changes predominantly in $\mathrm{Ca}^{2+}, \mathrm{Na}^{+}$, and $\mathrm{K}^{+}$transporting ATPase transcripts. These data suggest that Li affects membrane potentials and electrophysiological properties of cells in the amygdala.

It is important to emphasize that we tested normal rats in the present study; no genetic models of BPD exist. Although the data show that normal rats might be unfavorably affected by Li treatment (and, by inference, the results might caution against treating juveniles with $\mathrm{Li}$ in cases in which the clinical diagnosis is equivocal), they should be considered in light of the positive impact Li can have in the management of BPD. In children and adolescents, BPD is not only characterized by anxiety but also by irritability and disruptive behavior with features of ADHD and conduct disorder (http://www.nimh.nih.gov/publicat/bipolarupdate.cfm). These other behaviors were not addressed in our study. Genetic manipulations that can mimic some of these symptoms are needed to further address the effect of Li on BPDlike behaviors.

\section{References}

Alonso T, Morgan RO, Marvizon JC, Zarbl H, Santos E (1988) Malignant transformation by ras and other oncogenes produces common alterations in inositol phospholipid signaling pathways. Proc Natl Acad Sci USA 85:4271-4275.

American Psychiatric Association (1994) Practice guideline for the treatment of patients with bipolar disorder. American Psychiatric Association. Am J Psychiatry 151:1-36.

Andersen SL (2003) Trajectories of brain development: point of vulnerability or window of opportunity? Neurosci Biobehav Rev 27:3-18.

Bailey CH, Bartsch D, Kandel ER (1996) Toward a molecular definition of long-term memory storage. Proc Natl Acad Sci USA 93:13445-13452.

Baraban JM, Worley PF, Snyder SH (1989) Second messenger systems and psychoactive drug action: focus on the phosphoinositide system and lithium. Am J Psychiatry 146:1251-1260.

Berridge MJ, Downes CP, Hanley MR (1982) Lithium amplifies agonistdependent phosphatidylinositol responses in brain and salivary glands. Biochem J 206:587-595.

Berry GT, Buccafusca R, Greer JJ, Eccleston E (2004) Phosphoinositide deficiency due to inositol depletion is not a mechanism of lithium action in brain. Mol Genet Metab 82:87-92.

Biederman J, Mick E, Bostic JQ, Prince J, Daly J, Wilens TE, Spencer T, Garcia-Jetton J, Russell R, Wozniak J, Faraone SV (1998) The naturalistic course of pharmacologic treatment of children with maniclike symptoms: a systematic chart review. J Clin Psychiatry 59:628-637; quiz 638.

Biederman J, Mick E, Hammerness P, Harpold T, Aleardi M, Dougherty M, Wozniak J (2005) Open-label, 8-week trial of olanzapine and risperidone for the treatment of bipolar disorder in preschool-age children. Biol Psychiatry 58:589-594.

Bolstad BM, Irizarry RA, Astrand M, Speed TP (2003) A comparison of normalization methods for high density oligonucleotide array data based on variance and bias. Bioinformatics 19:185-193.

Brandish PE, Su M, Holder DJ, Hodor P, Szumiloski J, Kleinhanz RR, Forbes JE, McWhorter ME, Duenwald SJ, Parrish ML, Na S, Liu Y, Phillips RL, Renger JJ, Sankaranarayanan S, Simon AJ, Scolnick EM (2005) Regula- 
tion of gene expression by lithium and depletion of inositol in slices of adult rat cortex. Neuron 45:861-872.

Brett RR, Pratt JA (1990) Chronic handling modifies the anxiolytic effect of diazepam in the elevated plus-maze. Eur J Pharmacol 178:135-138.

Brown JS, Kalish HI, Farber IE (1951) Conditioned fear as revealed by magnitude of startle response to an auditory stimulus. J Exp Psychol 41:317-328.

Cappeliez P (1986) Comparing oral lithium carbonate and intraperitoneal lithium chloride chronic administrations on rats' activity levels. Neuropsychobiology 16:103-108.

Carlezon Jr WA, Konradi C (2004) Understanding the neurobiological consequences of early exposure to psychotropic drugs: linking behavior with molecules. Neuropharmacology 47 [Suppl 1]:47-60.

Carlezon Jr WA, William A, Rohan ML, Mague SD, Meloni EG, Parsegian A, Cayetano K, Tomasiewicz HC, Rouse ED, Cohen BM, Renshaw PF (2005) Antidepressant-like effects of cranial stimulation within a lowenergy magnetic field in rats. Biol Psychiatry 57:571-576.

Carlson GA (1990) Child and adolescent mania-diagnostic considerations. J Child Psychol Psychiatry 31:331-341.

Carlson GA, Davenport YB, Jamison K (1977) A comparison of outcome in adolescent- and later-onset bipolar manic-depressive illness. Am J Psychiatry 134:919-922.

Chang K, Karchemskiy A, Barnea-Goraly N, Garrett A, Simeonova DI, Reiss A (2005) Reduced amygdalar gray matter volume in familial pediatric bipolar disorder. J Am Acad Child Adolesc Psychiatry 44:565-573.

Crawley JN (1985) Exploratory behavior models of anxiety in mice. Neurosci Biobehav Rev 9:37-44.

Dahlquist KD, Salomonis N, Vranizan K, Lawlor SC, Conklin BR (2002) GenMAPP, a new tool for viewing and analyzing microarray data on biological pathways. Nat Genet 31:19-20.

Davanzo PA, McCracken JT (2000) Mood stabilizers in the treatment of juvenile bipolar disorder. Advances and controversies. Child Adolesc Psychiatr Clin N Am 9:159-182.

Davis M (1997) Neurobiology of fear responses: the role of the amygdala. J Neuropsychiatry Clin Neurosci 9:382-402.

Davis M, Astrachan DI (1978) Conditioned fear and startle magnitude: effects of different footshock or backshock intensities used in training. J Exp Psychol Anim Behav Process 4:95-103.

Dawson GR, Tricklebank MD (1995) Use of the elevated plus maze in the search for novel anxiolytic agents. Trends Pharmacol Sci 16:33-36.

Dennis Jr G, Sherman BT, Hosack DA, Yang J, Gao W, Lane HC, Lempicki RA (2003) DAVID: database for annotation, visualization, and integrated discovery. Genome Biol 4:P3.

Dickstein DP, Rich BA, Binstock AB, Pradella AG, Towbin KE, Pine DS, Leibenluft E (2005) Comorbid anxiety in phenotypes of pediatric bipolar disorder. J Child Adolesc Psychopharmacol 15:534-548.

D’Hooge R, De Deyn PP (2001) Applications of the Morris water maze in the study of learning and memory. Brain Res Rev 36:60-90.

Doniger SW, Salomonis N, Dahlquist KD, Vranizan K, Lawlor SC, Conklin BR (2003) MAPPFinder: using Gene Ontology and GenMAPP to create a global gene-expression profile from microarray data. Genome Biol 4:R7.

Engstrom C, Brandstrom S, Sigvardsson S, Cloninger R, Nylander PO (2003) Bipolar disorder. II. Personality and age of onset. Bipolar Disord 5:340-348.

Geller B, Luby J (1997) Child and adolescent bipolar disorder: a review of the past 10 years. J Am Acad Child Adolesc Psychiatry 36:1168-1176.

Geller B, Sun K, Zimerman B, Luby J, Frazier J, Williams M (1995) Complex and rapid-cycling in bipolar children and adolescents: a preliminary study. J Affect Disord 34:259-268.

Geller B, Williams M, Zimerman B, Frazier J, Beringer L, Warner KL (1998) Prepubertal and early adolescent bipolarity differentiate from ADHD by manic symptoms, grandiose delusions, ultra-rapid or ultradian cycling. J Affect Disord 51:81-91.

Grillon C, Davis M (1997) Fear-potentiated startle conditioning in humans: explicit and contextual cue conditioning following paired versus unpaired training. Psychophysiology 34:451-458.

Harpaz-Rotem I, Leslie DL, Martin A, Rosenheck RA (2005) Changes in child and adolescent inpatient psychiatric admission diagnoses between 1995 and 2000. Soc Psychiatry Psychiatr Epidemiol 40:642-647.

Harwood AJ (2005) Lithium and bipolar mood disorder: the inositoldepletion hypothesis revisited. Mol Psychiatry 10:117-126.

Hechtman L, Greenfield B (1997) Juvenile onset bipolar disorder. Curr Opin Pediatr 9:346-353.

Huang M, Chida K, Kamata N, Nose K, Kato M, Homma Y, Takenawa T,
Kuroki T (1988) Enhancement of inositol phospholipid metabolism and activation of protein kinase $\mathrm{C}$ in ras-transformed rat fibroblasts. J Biol Chem 263:17975-17980.

Irizarry RA, Hobbs B, Collin F, Beazer-Barclay YD, Antonellis KJ, Scherf U, Speed TP (2003) Exploration, normalization, and summaries of high density oligonucleotide array probe level data. Biostatistics 4:249-264.

Joyce PR (1984) Age of onset in bipolar affective disorder and misdiagnosis as schizophrenia. Psychol Med 14:145-149.

Kafantaris V, Coletti DJ, Dicker R, Padula G, Kane JM (2003) Lithium treatment of acute mania in adolescents: a large open trial. J Am Acad Child Adolesc Psychiatry 42:1038-1045.

Klann E, Dever TE (2004) Biochemical mechanisms for translational regulation in synaptic plasticity. Nat Rev Neurosci 5:931-942.

Konradi C (2005) Gene expression microarray studies in polygenic psychiatric disorders: applications and data analysis. Brain Res Brain Res Rev 50:142-155.

Kowatch RA, Suppes T, Carmody TJ, Bucci JP, Hume JH, Kromelis M, Emslie GJ, Weinberg WA, Rush AJ (2000) Effect size of lithium, divalproex sodium, and carbamazepine in children and adolescents with bipolar disorder. J Am Acad Child Adolesc Psychiatry 39:713-720.

Laursen UH, Pihakaski-Maunsbach K, Kwon TH, Ostergaard Jensen E, Nielsen S, Maunsbach AB (2004) Changes of rat kidney AQP2 and Na, K-ATPase mRNA expression in lithium-induced nephrogenic diabetes insipidus. Nephron Exp Nephrol 97:E1-E16.

LeDoux J (2003) The emotional brain, fear, and the amygdala. Cell Mol Neurobiol 23:727-738.

Lee RV, Jampol LM, Brown WV (1971) Nephrogenic diabetes insipidus and lithium intoxication-complications of lithium carbonate therapy. $\mathrm{N}$ Engl J Med 284:93-94.

Lewinsohn PM, Klein DN, Seeley JR (1995) Bipolar disorders in a community sample of older adolescents: prevalence, phenomenology, comorbidity, and course. J Am Acad Child Adolesc Psychiatry 34:454-463.

Li C, Wong WH (2001) Model-based analysis of oligonucleotide arrays: expression index computation and outlier detection. Proc Natl Acad Sci USA 98:31-36.

MacDonald ML, Eaton ME, Dudman JT, Konradi C (2004) Antipsychotic drugs elevate mRNA levels of presynaptic proteins in the frontal cortex of the rat. Biol Psychiatry 57:1041-1051.

Masi G, Toni C, Perugi G, Mucci M, Millepiedi S, Akiskal HS (2001) Anxiety disorders in children and adolescents with bipolar disorder: a neglected comorbidity. Can J Psychiatry 46:797-802.

Paxinos G, Watson C (1998) The rat brain in stereotaxic coordinates, Ed 4. San Diego: Academic.

Pellow S, Chopin P, File SE, Briley M (1985) Validation of open:closed arm entries in an elevated plus-maze as a measure of anxiety in the rat. J Neurosci Methods 14:149-167.

Perlis RH, Sachs GS, Lafer B, Otto MW, Faraone SV, Kane JM, Rosenbaum JF (2002) Effect of abrupt change from standard to low serum levels of lithium: a reanalysis of double-blind lithium maintenance data. Am J Psychiatry 159:1155-1159.

Sheard MH (1975) Lithium in the treatment of aggression. J Nerv Ment Dis 160:108-118

Silva AJ (2003) Molecular and cellular cognitive studies of the role of synaptic plasticity in memory. J Neurobiol 54:224-237.

Silva RR, Ernst M, Campbell M (1993) Lithium and conduct disorder. Encephale 19:585-590.

Singer I, Rotenberg D, Puschett JB (1972) Lithium-induced nephrogenic diabetes insipidus: in vivo and in vitro studies. J Clin Invest 51:1081-1091.

Spear LP (2004) Adolescent brain development and animal models. Ann NY Acad Sci 1021:23-26.

Steele M, Fisman S (1997) Bipolar disorder in children and adolescents: current challenges. Can J Psychiatry 42:632-636.

Treit D, Menard J, Royan C (1993) Anxiogenic stimuli in the elevated plusmaze. Pharmacol Biochem Behav 44:463-469.

Tueth MJ, Murphy TK, Evans DL (1998) Special considerations: use of lithium in children, adolescents, and elderly populations. J Clin Psychiatry 59 [Suppl 6]:66-73.

Williams RS, Cheng L, Mudge AW, Harwood AJ (2002) A common mechanism of action for three mood-stabilizing drugs. Nature 417:292-295.

Wozniak J, Biederman J, Richards JA (2001) Diagnostic and therapeutic dilemmas in the management of pediatric-onset bipolar disorder. J Clin Psychiatry 62 [Suppl 14]:10-15. 